\title{
An Economics Perspective of Plea Bargaining
}

\author{
Anita Banerjee \\ Assistant Professor of Economics \\ Andaman Law College, Port Blair, Andaman and Nicobar Island
}

\section{OPEN ACCESS}

Volume: 7

Issue: 1

Month: July

Year: 2019

ISSN: $2321-788 \mathrm{X}$

Received: 17.05.2019

Accepted: 25.06.2019

Published: 01.07.2019

Citation:

Banerjee, Anita. "An

Economics Perspective of

Plea Bargaining." Shanlax

International Journal

of Arts, Science and

Humanities, vol. 7, no. 1, 2019, pp. 56-60.

DOI:

https://doi.org/10.34293/

sijash.v7i1.498

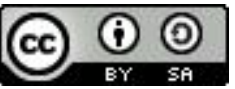

This work is licensed

\section{Abstract}

The present study is an attempt to look at plea bargaining from an economics perspective. At the outset it traces the origin of plea bargaining. The study also provides a brief sketch of the concept as interpreted by various Economists. Alongside it highlights some of the key tools of economics which can provide a better understanding and justification of Plea bargaining as a procedure for efficient and cost effective method of resolving cases. The article concludes by stressing upon the need to resort to plea bargaining, keeping in mind both the costs as well as a tool to act as deterrence.

Keywords: Plea Bargaining, Costs, Criminal, Deterrence.

\section{Introduction}

To begin with what exactly is plea bargaining? In simple words it means an agreement reached between the prosecution and the defendant whereby the latter tries to swap a deal by pleading guilty in return for leniency in punishment. In the process a full trial is avoided. Thus, the defendant waives his right to a full legal trial in return for concessions in punishment which would have occurred if they had gone for conviction after a full trial.

The Black's Law Dictionary defines plea bargaining as "The process whereby the accused and the prosecutor in a criminal case, work out a mutually satisfactory disposition of the case Subject to the Court approval. It usually involves the accused pleading the guilty to a lesser offence or to only one or some of the courts of multi-count indictment in return for a lighter than that possible for the graver charge"'.

But first before embarking upon the economics of plea bargaining it is pertinent to understand how and when plea bargaining came into existence, what necessitated the adoption of such a method and which was the first country to implement it. Practitioners and Scholars are not agreed on the exact meaning of plea bargaining. Like the proverbial elephant that was subject of description by various blind men, plea bargaining can be described in diverse ways depending on the perception of each practitioner or scholar. Thus, stated the present article attempts to look upon and discuss the concept of plea bargaining from the perspective of a student of Economics. The study attempts to provide a brief sketch of the economics of plea bargaining by analyzing the various concepts/ tools of economics which have been used by various Economists lawyers to understand the economics of plea bargaining. Researcher traces the history of plea bargaining in the world and in India and finally dwells upon the application of the same in Indian context.

under a Creative Commons

Attribution-ShareAlike 4.0

International License

1 Black Law dictionary, 2004 
History of Plea Bargaining: There is no doubt that the practice of plea bargain is rooted in common law, from the Medieval English Common Law court of guilty pardons to accomplices in felony cases. In modern times however, the significance it has acquired and the popularity it has gained can be attributed to the United States of America.

Origin of plea bargaining can be traced to United States of America. It is said that cases of plea bargaining reached official records in the years following the American Civil war. The reaction towards such cases was a strong disapproval. However after the American civil war cases of plea bargaining began to appear in American appellate court reports ${ }^{2}$. More than $75 \%$ of the criminal cases in America is resolved through plea bargaining. Indian judiciary did not look upon plea bargaining as an appropriate means to settle court cases. In view of the large number of cases pending in the courts and on the recommendations of law commission (154th) report suggested plea bargaining as an alternate method to deal with the huge arrears of criminal cases. Thus it was implemented through criminal law (Amendment) Act 2005.

\section{Economics Approach to Plea Bargaining:}

The discipline of Economics in particular the concepts have become indispensable for arriving at a reasonable solution to issues concerned with costs and the accompanying benefits. The economics literature on criminal justice system, originated with Gary Beckers seminal paper on the topic in 1968. About the same time when Economics as a discipline was trying to make its presence felt in the discipline of law, Landes (1971) and Grossman and Katz (1983), takes the existence of plea bargaining as a given, and focuses on analyzing its ect or discussing adjustments that would improve it ${ }^{3}$.

Gary Becker $(\mathbf{1 9 6 8})^{4}$ : Becker says that the term "crime" covers all forms of violations, not just felonies like murder, robbery and assault, which usually receive a lot of attention but also tax evasion, traffic and other white collar crimes, thus making "crime" an important aspect which Economist have

2 Albert Alschuler, plea bargaining and its history, University of Chicago Law school, 1979

3 Baker and Mezzetti, 2001

4 Gary Becker, Crime and Punishment: An economic Approach in http://www.nber.org/chapters/c3625 often tended to neglect.

Landes (1971): Market based models of plea bargaining was first introduced by Landes. The most important assumption on which the model is based is that of maximization of benefit / utility. Both the defendant and the prosecutor aims at maximizing their respective utility subject to constraints, in particular the task of a prosecutor is maximizing "deterrence" which put in the form of an equation as follows:

$$
\begin{aligned}
& \mathrm{P}=\mathrm{P}\left(\mathrm{R}^{*}, \mathrm{R} ; \mathrm{Z}\right) \\
& \mathrm{P}^{*}=\mathrm{P}^{*}\left(\mathrm{R}^{*}, \mathrm{R} ; \mathrm{Z}\right)
\end{aligned}
$$

Where $\mathrm{P}$ and $\mathrm{P}^{*}$ stand for Prosecutor and defendant's respective estimates of probability of conviction in a trial. $\mathrm{R}$ represents respective expenditure of resources by both the parties concerned, whereas $\mathrm{Z}$ represents other factors such as availability of witness, defendant's past records, his alibi etc. Another assumption is that there are no court costs/ transaction costs and that the sentence is independent of resource allocation. From the assumptions Landes draws some implications which are 1) a negotiated sentence will tend to be shorter as the probability of conviction at trial diminishes; (2) the shorter the sentence associated with the charged offense, the more settlement is likely; (3) if both the defendant and prosecutor agree on the probability of conviction, settlements will take place in cases where the defendant is risk averse, or risk neutral, however not necessarily when the defendant is a risk seeker; and (4) when the prosecutor and defendant differ in their estimates of conviction at trial, if the prosecutor's assessment of conviction is lower, even risk preferring defendants will settle due to the ability to extract concession. Thus what Landes argues is that a plea bargaining will take place only when it is in the interest of both the parties.

Grossman and Katz (1983): Taking forward the argument advanced by Landes, Grossman and Katz assumes further that all defendants are "risk averse" hence they go for "self screening" and that probability of conviction of a truly guilty defendant is much more than the probability of conviction of a innocent defendant. Thus the "self selection" of guilty defendants will induce them to go for plea bargaining rather than stand trial. 
Richard Aldestein ${ }^{5}$ : Continuing with Landes approach, Aldestein emphasizes rational behavior on the part of both the defendants and the prosecutors. At the same time distinguishes the approach to plea bargaining in to two parts. The first is the neo classical foundations of optimization and efficient equilibrium focusing on the bargaining power of the defendants and the prosecutors. This model tries to build a mathematically precise actual outcome of bargaining or in prescribing a hypothetically systemic efficient allocation of resources for the entire criminal process. The second approach is based on the foundations of institutional economics and its focus on facilitation of individual transactions, treating the existing institutions of criminal justice in historical context and proposes comparative analysis of different legal systems as they struggle to allocate limited, judicial and prosecutorial resources to achieve different concepts of criminal justice.

Reinganum (1988) ${ }^{6}$ : Reinganum has also analyzed plea bargaining by adding another concept prevalent in economics that is of "asymmetrical information". Both sides that are the defendants and the prosecutor have asymmetrical information about the other. The defendant alone knows with certainty about his guilt or innocence similarly, the prosecutor has knowledge about the probability of conviction. This information cannot be communicated, because each side will reveal only that part of the information which will help them. She concludes that more strong the prosecutor's case, the more probability of a trial, because the defendants will not go for a "bad bargain".

Richard Posner $(\mathbf{2 0 0 3})^{7}$ : provides an overview of plea bargaining. He begins his analysis by arguing that the standard criticisms of plea bargaining are incorrect. These criticisms are that, from the defendant's side, it denies a defendant's right to trial, and that from the prosecutor's side, it leads to shorter

5 Richard Adelstein (2007), Economics of Plea bargaining in Wesleyan University, Division II Faculty Publication

6 Reinganum, Jennifer F. 1988, "Plea Bargaining and Prosecutorial Discretion." The American Economic Review 78(4): 713-728

7 Richard A. Posner,1975, Economic Approach to Law in University of Chicago Law School, Chicago Bound, Journal articles sentences. Posner suggests that these criticisms are both incorrect as, "If a settlement did not make both parties to a criminal case better off than if they went to trial, one or the other would invoke his right to trial" (Posner 2003: 578)

Additionally, Posner argues that an abolition of plea bargaining would lead to longer waiting times for criminal defendants. This, he argues, would increase expected costs for those defendants held without bail before trial, common under the Bail Reform Act of 1984, especially for those who are actually innocent.

Besides there are some other concepts in Economics that can be used to justify Plea Bargaining a few of which are Rational Behavior, scarcity of resources, utility maximization, prisoners' dilemma, Pareto optimality etc.

Rational Behavior: The very foundation of economics is based upon the assumption that every individual is guided by and exhibits a rational behavior. It means the purpose of every individual in a society is to maximize his benefits and minimize the costs in every transaction that he/she undertakes. In case of criminal cases both the defendant as well as the prosecutor seeks to maximize benefit from their respective stand point.

Prisoner's Dilemma: In a way plea bargaining is comparable to a situation of Prisoner's Dilemma, where the defendants are given a choice of collectively cooperating and making a choice or individually each one of the prisoner is better off by avoiding cooperation. Prisoner's dilemma is actually a plea bargaining dilemma. If both collectively defect they will be in a worst off situation and will get a longer sentence. Thus there is a direct relationship between longer sentences to the defendants and enhanced prosecutorial costs that is lengthier a sentence given to a defendant, the more the related expenditure. As is evident from the diagram given below.

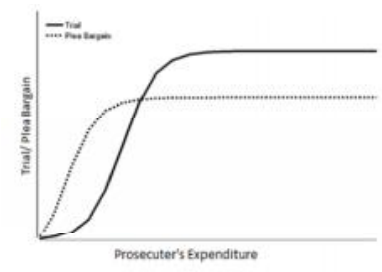

Pareto Optimality: An allocation of resources 
is pareto superior to an alternate allocation if and only if no person is disadvantaged by it and the lot of at least one person is improved. Ronald Coase ${ }^{8}$ has used this concept to explain that in the absence of transaction costs, a pareto optimal situation can be achieved which will not harm anyone but benefit both the parties concerned. Transaction costs as defined by Coase's theorem are the cost incurred in order to maintain and protect the rights in the context of criminal law, it relates to the cost of maintaining of jails, police, courts, compensation, rights and protection of civilians are all included in transaction costs.

Plea Bargaining in India: In India Plea bargaining was introduced after an amendment under the criminal law (Amendment) Act 2005. Unfortunately the economics of plea bargaining is not properly understood in the Indian context and hence it has evoked mixed responses. Major changes in the Indian judicial system took place after the concept of plea bargaining was given official recognition under the code of criminal procedure. Perhaps understanding the need for cheap and expeditious settlement of cases including criminal cases The Gujarat High Court (in State of Gujarat v NatwarHarchanji Thakur) endorsed the concept of plea bargaining as a measure of redressal and also observed that it has added a new dimension in the realm of judicial reforms ((2005) Cr. L.J. 2957).

\section{Percentage of total inmates}

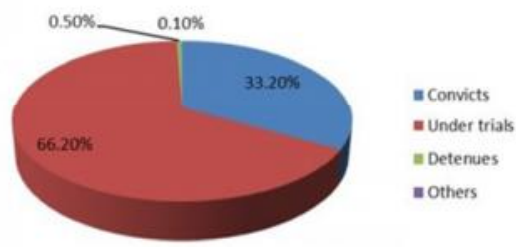

The number of pending cases has constantly been on the rise, as is evident from the diagram. As per PTI (2014, press Trust of India) there are more than $3 \mathrm{Cr}$. Pending cases. Data from prison statistics show

8 Guido Calabresi and A. Douglas Melamed, Property Rules, Liability Rules, and In alienability: One view of the Cthedrala, 85 (6), Harvard law Review 1089 (1972) that states spend Rs. 51 per inmate daily on food, medicine etc. Ironical though it may sound, this said amount is more than the figure fixed as poverty line by Rangarajan committee (Rs. 47 per day for urban areas and Rs. 32 per day for rural areas). The figure below shows the expenditure on food, clothing and medicine per inmate in Rupees 2014, state wise.

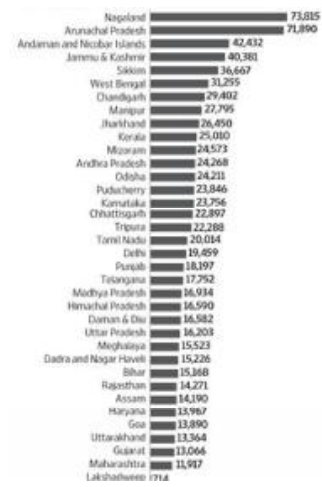

Source: Prison Statistics , India, 2014.

The prison statistics India 2015 released by NCRB states that overcrowding is one of the biggest problem faced by theprison inmates. The occupancy rate at the all India level at the end of 2015 was 114.4 per cent. Thirdly two third of the prisoners are under trials, languishing in jails, not yet convicted for a crime.

\section{Conclusion}

Backlogs in resolving cases is a major lacuna of Indian judicial system. Moreover it is said that the right to speedy trial is a fundamental right under Article 21 of the Constitution. From the above views on the concept of plea bargaining it becomes clear that the use of economics based tools such as efficiency, rationality, cost effectiveness in resolving cases through plea bargaining could definitely help in speedily disposing of large number of cases, expeditiously. More conscious use of Economic theories which still happens to be very rare, particularly in the Indian context could definitely lead to cost effective and time saving solutions taking also into account moral propriety of a particular decision. Cost reduction and saving of time are certainly a very important reason which requires a proper analysis and understanding of the economics of plea bargain keeping in mind that it should be used to maximise deterrence as well as 
minimise the cost of prosecution.

\section{References}

Adelstein, Richard. "The Negotiated Guilty Plea:

A Framework for Analysis." New York University Law Review, vol. 53, no. 4, 1978, pp. 783-833.

Algan, Yann and Pierre Cahuc. "Inherited Trust and Growth." The American Economic Review, vol. 100, no. 5, 2010, pp. 2060-2092.

Adelstein, Richard and Thomas Miceli. "Toward a Comparative Economics of Plea Bargaining." European Journal of Law and Economics, vol. 11, no. 1, 2001, pp. 47-67.
Bar-Gill, Oren and Omri Ben-Shahar. "The Prisoners' (Plea Bargain) Dilemma." Journal of Legal Analysis, vol. 1, no. 2, 2009, pp. 737-773.

JR., Thomas W.Church. "In Defense of "Bargain Justice." Law and Society Review, vol. 13, no. 2, pp. 509-525.

Hatalak, Oskanna, et al. The International Crime Victim Survey in Countries in Transition. United Nations Interregional Crime and Justice Research Institute, 1998.

Landes, William M. "An Economic Analysis of the Courts." Journal of Law and Economics, vol. 14, no. 1, 1971, pp. 61-107.

\section{Author Details}

Anita Banerjee, Assistant Professor of Economics, Andaman Law College, Port Blair, Andaman and Nicobar

Email ID: anitamondal_isher@rediffmail.com 